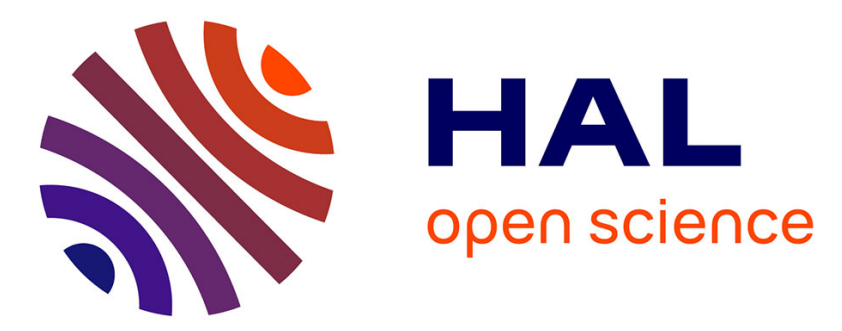

\title{
Systematic investigation of the antiproliferative activity of a series of ruthenium terpyridine complexes
}

Johannes Karges, Olivier Blacque, Marta Jakubaszek, Bruno Goud, Philippe Goldner, Gilles Gasser

\section{To cite this version:}

Johannes Karges, Olivier Blacque, Marta Jakubaszek, Bruno Goud, Philippe Goldner, et al.. Systematic investigation of the antiproliferative activity of a series of ruthenium terpyridine complexes. Journal of Inorganic Biochemistry, 2019, pp.110752. 10.1016/j.jinorgbio.2019.110752 . hal-02160031

\section{HAL Id: hal-02160031 \\ https://hal.science/hal-02160031}

Submitted on 19 Jun 2019

HAL is a multi-disciplinary open access archive for the deposit and dissemination of scientific research documents, whether they are published or not. The documents may come from teaching and research institutions in France or abroad, or from public or private research centers.
L'archive ouverte pluridisciplinaire HAL, est destinée au dépôt et à la diffusion de documents scientifiques de niveau recherche, publiés ou non, émanant des établissements d'enseignement et de recherche français ou étrangers, des laboratoires publics ou privés. 


\title{
Systematic Investigation of the Antiproliferative Activity of a Series of Ruthenium Terpyridine Complexes
}

\author{
Johannes Karges, ${ }^{a}$ Olivier Blacque, ${ }^{b}$ Marta Jakubaszek, ${ }^{a, c}$ Bruno Goud, ${ }^{c}$ Philippe Goldner ${ }^{d}$ \\ and Gilles Gasser ${ }^{a * *}$
}

a Chimie ParisTech, PSL University, CNRS, Institute of Chemistry for Life and Health Sciences, Laboratory for Inorganic Chemical Biology, 75005 Paris, France.

b Department of Chemistry, University of Zurich, Winterthurerstrasse 190, 8057 Zurich, Switzerland.

c Institut Curie, PSL University, CNRS UMR 144, Paris, France.

d Chimie ParisTech, PSL University, CNRS, Institut de Recherche de Chimie Paris, 75005 Paris, France.

*Email: gilles.gasser@chimieparistech.psl.eu; www.gassergroup.com; Tel. +33 144275602.

ORCID-ID:

Johannes Karges: 0000-0001-5258-0260

Olivier Blacque: 0000-0001-9857-4042

Marta Jakubaszek: 0000-0001-7590-2330

Bruno Goud: 0000-0003-1227-4159

Philippe Goldner: 0000-0001-8517-0911

Gilles Gasser: 0000-0002-4244-5097 


\title{
Keywords
}

Anticancer, Medicinal Inorganic Chemistry, Metals in Medicine, Photodynamic Therapy, Ruthenium.

\begin{abstract}
Due to acquired resistance or limitations of the currently approved drugs against cancer, there is an urgent need for the development of new classes of compounds. Among others, there is an increasing attention towards the use of $\mathrm{Ru}(\mathrm{II})$ polypyridyl complexes. Most studies in the literature were made on complexes based on the coordination of $\mathrm{N}$-donating bidentate ligands to the ruthenium core whereas studies on $2,2^{\prime}: 6^{\prime}, 2^{\prime \prime}$-terpyridine (terpy) coordinating ligands are relatively scare. However, several studies have shown that $[\mathrm{Ru}(\text { terpy }) 2]^{2+}$ derivatives are able bind to DNA through various binding modes making these compounds potentially suitable as chemotherapeutic agents. Additionally, light irradiation of these compounds was shown to enable DNA cleavage, highlighting their potential use as photosensitizers (PSs) for photodynamic therapy (PDT). In this work, we present the systematic investigation of the potential of 7 complexes of the type $[\mathrm{Ru}($ terpy)(terpy-X) $] 2+(\mathrm{X}=\mathrm{H}(\mathbf{1}), \mathrm{Cl}(\mathbf{2}), \mathrm{Br}(\mathbf{3}), \mathrm{OMe}$
\end{abstract} (4), $\mathrm{COOH}(5), \mathrm{COOMe}(6), \mathrm{NMe} 2(7))$ as potential chemotherapeutic agents and PDT PSs. Importantly, six of the seven complexes were found to be stable in human plasma as well as photostable in acetonitrile upon continuous light irradiation $(480 \mathrm{~nm})$. The determination of the distribution coefficient $\log P$ values for the 7 complexes revealed their good water solubility. Complex 7 was found to be cytotoxic in the micromolar range in the dark as well as to have some phototoxicity upon light exposure at $480 \mathrm{~nm}$ in non-cancerous retinal pigment epithelium (RPE-1) and cancerous human cervical carcinoma (HeLa) cells.

\section{Introduction}


Based on the increasing impact of cancer on the life quality as well as mortality in the world, research efforts are made towards the development of new methods for the treatment of this disease as well as the improvement of existing anticancer drugs. Most commonly, cancer is fought through the combination of different techniques (i.e. chemotherapy, surgery, radiotherapy and immunotherapy).[1-3] To date, the gold standard in the chemotherapeutic treatment of cancer is the platinum drug cisplatin and its derivatives carboplatin and oxaliplatin. $[4,5]$ However, although the ability of cisplatin for the treatment of patients with cancer is impressive and undeniable, treatments with this drug are also associated with severe side effects that include nerve and kidney damage, nausea, vomiting and bone marrow suppression. Acquired resistances limit also the use of cisplatin and this derivatives. These drawbacks have led, in the last decades, to the search for alternative compounds and, among others, of non-platinum based compounds. Among the new classes investigated, coordinatively saturated, inert $\mathrm{Ru}(\mathrm{II})$ polypyridyl complexes are receiving increasing attention due to their promising anticancer and antimicrobial activity as chemotherapeutic agents as well as photodynamic therapy (PDT) photosensitizers (PSs).[6-17] Very importantly, one of Mc Farland and co-workers' ruthenium-based PDT PSs, namely TLD-1433, just completed phase I clinical trial as a PDT PS against bladder cancer.[10]

In the field of ruthenium-based PDT PSs, most studies in the literature are based on a $\left[\mathrm{Ru}(\text { bipy/phen/bphen/dppz) } 3]^{2+}\right.$ (bipy $=2,2$ '-bipyridine, phen $=1,10$-phenanthroline, bphen $=$ 4,7-diphenyl-1,10-phenanthroline, dppz $=$ dipyrido[3,2-a:2',3'-c]phenazine) scaffold due to their interesting redox properties, long excited-state lifetimes as well as intense luminescence.[11, 13, 18-24] In comparison, complexes based on a $\left[\mathrm{Ru}\left(\text { terpy) }{ }_{2}\right]^{2+}\right.$ (terpy $=2,2^{\prime}: 6^{\prime}, 2^{\prime \prime}$-terpyridine) scaffold have not been very extensively studied. These complexes are well-known to have a short-lived excited state and to be weakly luminescent at room 
temperature but long-lived and strongly luminescent at low temperature $(77 \mathrm{~K})$. This phenomenon is explained by an unfavourable bite angle of the ligands for the octahedral coordination of the $\mathrm{Ru}(\mathrm{II})$. As a result, a relatively low ligand field state ${ }^{3} \mathrm{LF}$ (ligand-field) is created which is able to quench the normally emitting ${ }^{3}$ MLCT (metal-to-ligand charge-transfer) state.[20,25] Despite these unfavourable photophysical properties, several studies have shown that these complexes were still able to bind to DNA and to cleave it upon light irradiation, making them potential PSs for PDT purposes.[26-30] Interestingly, it was demonstrated that these complexes were able to interact in different manners with DNA, including electrostatic interactions, intercalation, and groove binding, depending on the substituents on the terpy ligand.[31-35]

In this work, we present the systematic investigation of the potential of $7 \mathrm{Ru}(\mathrm{II})$ complexes of the type $\left[\mathrm{Ru}(\right.$ terpy $)(\text { terpy-X) }]^{2+}(\mathrm{X}=\mathrm{H}(\mathbf{1}), \mathrm{Cl}(\mathbf{2}), \mathrm{Br}$ (3), OMe (4), COOH (5), COOMe (6), $\mathrm{NMe}_{2}(7)$ ) as potential chemotherapeutic agents and as PDT PSs. All investigated complexes were fully characterised by ${ }^{1} \mathrm{H}$ and ${ }^{13} \mathrm{C}-\mathrm{NMR}$, ESI-HRMS, elemental analysis as well as single crystal X-ray crystallography. As described below, one of the complexes (compound 7) was found to be cytotoxic in the micromolar range in the dark as well as to have some phototoxicity upon light exposure at $480 \mathrm{~nm}$, highlighting some potential for this type of complexes. 


\section{Experimental section}

\subsection{Materials}

All chemicals were obtained from commercial sources and used without further purification. Solvents were dried over molecular sieves if necessary. The $\mathrm{Ru}(\mathrm{II})$ precursor $\mathrm{Ru}($ terpy)Cl 3 was synthesised as previously published.[36] The substituted 2,2':6',2"'-terpyridine ligands (terpy$\mathrm{X})$ : 4'-chloro-2,2':6’,2”-terpyridine (terpy-Cl),[37] 4'-bromo-2,2':6’,2”-terpyridine (terpy$\mathrm{Br}$ ),[38] 4'-methoxy-2,2':6',2”-terpyridine (terpy-OMe),[39] 4'-carboxy-2,2':6',2”-terpyridine (terpy-COOH),[40] 4‘-methylcarboxy-2,2’:6’,2”-terpyridine (terpy-COOMe),[40] 4`dimethylamino-2,2':6',2"'-terpyridine (terpy-NMe2)[41] were synthesised as previously reported.

\subsection{Instrumentation and methods}

${ }^{1} \mathrm{H}$ and ${ }^{13} \mathrm{C}$ NMR spectra were recorded on a Bruker $400 \mathrm{MHz}$ NMR spectrometer. Chemical shifts $(\delta)$ are reported in parts per million (ppm) referenced to tetramethylsilane $(\delta 0.00)$ ppm using the residual proton solvent peaks as internal standards. Coupling constants $(\mathrm{J})$ are reported in Hertz (Hz) and the multiplicity is abbreviated as follows: s (singulet), d (doublet), dd (doublet of doublet), m (multiplet). ESI-MS experiments were carried out using a LTQ-Orbitrap XL from Thermo Scientific (Thermo Fisher Scientific, Courtaboeuf, France) and operated in positive ionization mode, with a spray voltage at $3.6 \mathrm{kV}$. No Sheath and auxiliary gas was used. Applied voltages were 40 and $100 \mathrm{~V}$ for the ion transfer capillary and the tube lens, respectively. The ion transfer capillary was held at $275^{\circ} \mathrm{C}$. Detection was achieved in the Orbitrap with a resolution set to $100,000($ at $\mathrm{m} / \mathrm{z} 400$ ) and a $\mathrm{m} / \mathrm{z}$ range between $150-2000$ in profile mode. Spectrum was analyzed using the acquisition software XCalibur 2.1 (Thermo Fisher Scientific, Courtaboeuf, France). The automatic gain control (AGC) allowed accumulation of up to $2 * 10^{5}$ ions for FTMS scans, maximum injection time was set to $300 \mathrm{~ms}$ and $1 \mu$ scan was acquired. 10 
$\mu \mathrm{L}$ was injected using a Thermo Finnigan Surveyor HPLC system (Thermo Fisher Scientific, Courtaboeuf, France) with a continuous infusion of methanol at $100 \mu \mathrm{L} \cdot \mathrm{min}^{-1}$. Elemental microanalyses were performed on a Thermo Flash 2000 elemental analyser.

\subsection{Synthesis}

$\left[\mathrm{Ru}(\text { terpy })_{2}\right]\left(\mathrm{PF}_{6}\right)_{2}(\mathbf{1})$

$\left[\mathrm{Ru}(\text { terpy })_{2} \mathrm{PF} 6\right)_{2}$ was synthesized as previously published.[42] Experimental data fits with the literature. Purity of the sample was assessed by HPLC and elemental analysis. Anal. Calc. for $\mathrm{C}_{30} \mathrm{H}_{22} \mathrm{~F}_{12} \mathrm{~N}_{6} \mathrm{P}_{2} \mathrm{Ru}: \mathrm{C} 42.02, \mathrm{H} 2.59$, N 9.80. Found: C 41.91, H 2.60, N 9.71.

$\left[\mathrm{Ru}(\right.$ terpy)$)($ terpy-Cl) $]\left(\mathrm{PF}_{6}\right)_{2}(\mathbf{2})$

The synthesis of $\left[\mathrm{Ru}(\right.$ terpy)(terpy-Cl) $]\left(\mathrm{PF}_{6}\right)_{2}$ was previously reported.[43] In this work, another synthetic route was employed. $\mathrm{Ru}($ terpy $) \mathrm{Cl}_{3}$ (200 mg, $0.45 \mathrm{mmol}, 1.0$ equiv.), 4‘-Chloro2,2':6',2"-terpyridine (terpy-Cl) (134 mg, $0.50 \mathrm{mmol}, 1.1$ equiv) and some drops of $\mathrm{N}$ ethylmorpholine were dissolved in $8: 2 \mathrm{EtOH} / \mathrm{H}_{2} \mathrm{O}(50 \mathrm{~mL})$. The mixture was heated under reflux for $4 \mathrm{~h}$ under nitrogen atmosphere. The crude product was cooled to room temperature and undissolved solid was filtered off over Celite. The solid was washed with EtOH, the solution concentrated and a sat. aqueous solution of $\mathrm{NH}_{4} \mathrm{PF}_{6}$ was added. The crude product, which precipitated as a $\mathrm{PF}_{6}$ salt was collected by centrifugation and washed with $\mathrm{EtOH}, \mathrm{H}_{2} \mathrm{O}$ and $\mathrm{Et}_{2} \mathrm{O}$. The product was isolated by column chromatography on silica gel with an $\mathrm{CH}_{3} \mathrm{CN} / \mathrm{aq}$. $\mathrm{KNO}_{3}(0.4 \mathrm{M})$ solution $(10: 1)$. The fractions containing the product were united and the solvent was removed under reduced pressure. The residue was dissolved in $\mathrm{CH}_{3} \mathrm{CN}$ and undissolved $\mathrm{KNO}_{3}$ was removed by filtration. The solvent was removed again and the product was dissolved in $\mathrm{H}_{2} \mathrm{O}(50 \mathrm{~mL})$. Upon addition of $\mathrm{NH}_{4} \mathrm{PF}_{6}$ the product precipitated as a $\mathrm{PF}_{6}$ salt. The solid was obtained by filtration and was washed three-times with $\mathrm{H}_{2} \mathrm{O}$ and $\mathrm{Et}_{2} \mathrm{O}$. Experimental data fits 
with the literature. Purity of the sample was assessed by HPLC and elemental analysis. ESIHRMS m/z: $301.0277[\mathrm{M}]^{2+}$, calcd for $\mathrm{C}_{30} \mathrm{H}_{21} \mathrm{ClN}_{6} \mathrm{Ru}$ 301.0274. Anal. Calc. for $\mathrm{C}_{30} \mathrm{H}_{21} \mathrm{ClF}_{12} \mathrm{~N}_{6} \mathrm{P} 2 \mathrm{Ru}+1.3 * \mathrm{H}_{2} \mathrm{O}:$ C 39.36, H 2.60, N 9.18. Found: C 38.99, H 2.50, N 9.68.

\section{$\left[\mathrm{Ru}(\right.$ terpy)(terpy-Br) $]\left(\mathrm{PF}_{6}\right)_{2}(\mathbf{3})$}

The synthesis of $\left[\mathrm{Ru}(\right.$ terpy $)($ terpy-Br) $]\left(\mathrm{PF}_{6}\right)_{2}$ was previously reported.[44] In this work, another synthetic route was employed. $\mathrm{Ru}$ (terpy) $\mathrm{Cl}_{3}$ (200 mg, $0.45 \mathrm{mmol}, 1.0$ equiv.), 4‘-Bromo2,2':6',2"'-terpyridine (terpy-Br) (156 mg, $0.50 \mathrm{mmol}, 1.1$ equiv) and some drops of $\mathrm{N}$ ethylmorpholine were dissolved in $8: 2 \mathrm{EtOH} / \mathrm{H}_{2} \mathrm{O}(50 \mathrm{~mL})$. The mixture was heated under reflux for $4 \mathrm{~h}$ under nitrogen atmosphere. The crude product was cooled to room temperature and undissolved solid was filtered off over Celite. The solid was washed with EtOH, the solution concentrated and a sat. aqueous solution of $\mathrm{NH}_{4} \mathrm{PF}_{6}$ was added. The crude product, which precipitated as a $\mathrm{PF}_{6}$ salt was collected by centrifugation and washed with $\mathrm{EtOH}, \mathrm{H}_{2} \mathrm{O}$ and $\mathrm{Et}_{2} \mathrm{O}$. The product was isolated by column chromatography on silica gel with an $\mathrm{CH}_{3} \mathrm{CN} / \mathrm{aq}$. $\mathrm{KNO}_{3}(0.4 \mathrm{M})$ solution $(10: 1)$. The fractions containing the product were united and the solvent was removed under reduced pressure. The residue was dissolved in $\mathrm{CH}_{3} \mathrm{CN}$ and undissolved $\mathrm{KNO}_{3}$ was removed by filtration. The solvent was removed again and the product was dissolved in $\mathrm{H}_{2} \mathrm{O}(50 \mathrm{~mL})$. Upon addition of $\mathrm{NH}_{4} \mathrm{PF}_{6}$ the product precipitated as a $\mathrm{PF}_{6}$ salt. The solid was obtained by filtration and was washed three-times with $\mathrm{H}_{2} \mathrm{O}$ and $\mathrm{Et}_{2} \mathrm{O}$. Experimental data fits with the literature. Purity of the sample was assessed by HPLC and elemental analysis. ESIHRMS m/z: $324.0020[\mathrm{M}]^{2+}$, calcd for $\mathrm{C}_{30} \mathrm{H}_{21} \mathrm{BrN}_{6} \mathrm{Ru}$ 324.0012. Anal. Calc. for $\mathrm{C}_{30} \mathrm{H}_{21} \mathrm{BrF}_{12} \mathrm{~N}_{6} \mathrm{P}_{2} \mathrm{Ru}+1 \mathrm{H}_{2} \mathrm{O}:$ C 37.75, H 2.43, N 8.81. Found: C 37.55, H 2.03, N 9.26.

$\left[\mathrm{Ru}(\right.$ terpy)$)($ terpy-OMe) $]\left(\mathrm{PF}_{6}\right)_{2}(\mathbf{4})$ 
$\mathrm{Ru}$ (terpy)Cl 3 (203 mg, $0.46 \mathrm{mmol}, 1.0$ equiv.), 4'-Methoxy-2,2’'6’,2”-terpyridine (terpy-Br) (133 mg, $0.51 \mathrm{mmol}, 1.1$ equiv) and some drops of $N$-ethylmorpholine were dissolved in 8:2 $\mathrm{EtOH} / \mathrm{H}_{2} \mathrm{O}(50 \mathrm{~mL})$. The mixture was heated under reflux for $5 \mathrm{~h}$ under nitrogen atmosphere. The crude product was cooled to room temperature and undissolved solid was filtered off over Celite. The solid was washed thoroughly with EtOH and afterwards the solvent was removed under reduced pressure. The residue was dissolved in $\mathrm{H}_{2} \mathrm{O}$ and a sat. aqueous solution of $\mathrm{NH}_{4} \mathrm{PF}_{6}$ was added. The crude product, which precipitated as a $\mathrm{PF}_{6}$ salt was collected by centrifugation and washed with $\mathrm{EtOH}, \mathrm{H}_{2} \mathrm{O}$ and $\mathrm{Et}_{2} \mathrm{O}$. The product was isolated by column chromatography on silica gel with an $\mathrm{CH}_{3} \mathrm{CN} /$ aq. $\mathrm{KNO}_{3}(0.4 \mathrm{M})$ solution (10:1). The fractions containing the product were united and the solvent was removed under reduced pressure. The residue was dissolved in $\mathrm{CH}_{3} \mathrm{CN}$ and undissolved $\mathrm{KNO}_{3}$ was removed by filtration. The solvent was removed again and the product was dissolved in $\mathrm{H}_{2} \mathrm{O}(50 \mathrm{~mL})$. Upon addition of $\mathrm{NH}_{4} \mathrm{PF}_{6}$ the product precipitated as a $\mathrm{PF}_{6}$ salt. The solid was obtained by filtration and was washed three-times with $\mathrm{H}_{2} \mathrm{O}$ and $\mathrm{Et}_{2} \mathrm{O}$. $257 \mathrm{mg}$ of $[\mathrm{Ru}($ terpy)(terpy-OMe)](PF6)2 (4) (0.29 mmol, $63 \%$ ) were yielded as a red solid. ${ }^{1} \mathrm{H}-\mathrm{NMR}\left(\mathrm{CD}_{3} \mathrm{CN}, 400 \mathrm{MHz}\right): \delta=8.72(\mathrm{~d}, J=8.2 \mathrm{~Hz}, 2 \mathrm{H})$, 8.50-8.46 (m, 4H), $8.36(\mathrm{t}, J=8.2 \mathrm{~Hz}, 1 \mathrm{H}), 8.33(\mathrm{~s}, 2 \mathrm{H}), 7.93-7.86(\mathrm{~m}, 4 \mathrm{H}), 7.42(\mathrm{ddd}, J=5.5$, 1.4, $0.7 \mathrm{~Hz}, 2 \mathrm{H}), 7.29$ (ddd, $J=5.5,1.4,0.7 \mathrm{~Hz}, 2 \mathrm{H}), 7.18$ (ddd, $J=7.5,5.61 .3 \mathrm{~Hz}, 2 \mathrm{H}), 7.12$ (ddd, $J=7.5,5.61 .3 \mathrm{~Hz}, 2 \mathrm{H}), 4.31(\mathrm{~s}, 3 \mathrm{H}) .{ }^{13} \mathrm{C}-\mathrm{NMR}\left(\mathrm{CD}_{3} \mathrm{CN}, 100 \mathrm{MHz}\right): \delta=167.6,158.8$, $158.6,156.5,156.4,153.3,152.8,138.5,138.4,135.7,128.0,127.9,125.0,124.8,124.1,111.3$, 57.8. ESI-HRMS m/z: $299.0527[\mathrm{M}]^{2+}$, calcd for $\mathrm{C}_{31} \mathrm{H}_{24} \mathrm{~N}_{6} \mathrm{O}_{1} \mathrm{Ru}$ 299.0522. Anal. Calc. for $\mathrm{C}_{31} \mathrm{H}_{24} \mathrm{~F}_{12} \mathrm{~N}_{6} \mathrm{O}_{2} \mathrm{P}_{2} \mathrm{Ru}: \mathrm{C}$ 41.95, H 2.73, N 9.47. Found: C 41.79, H 2.64, N 9.45.

$\left[\mathrm{Ru}(\right.$ terpy) (terpy-COOH) $]\left(\mathrm{PF}_{6}\right)_{2}(\mathbf{5})$

The synthesis of $\left[\mathrm{Ru}(\right.$ terpy)(terpy-COOH) $]\left(\mathrm{PF}_{6}\right)_{2}$ was previously reported.[45] In this work, another synthetic route was employed. $\mathrm{Ru}($ terpy)Cl 3 (200 mg, $0.45 \mathrm{mmol}, 1.0$ equiv.), 4`- 
Carboxy-2,2':6',2"-terpyridine (terpy-COOH) (139 mg, $0.50 \mathrm{mmol}, 1.1$ equiv) and some drops of $N$-ethylmorpholine were dissolved in $8: 2 \mathrm{EtOH} / \mathrm{H}_{2} \mathrm{O}(50 \mathrm{~mL})$. The mixture was heated under nitrogen atmosphere at reflux for $4 \mathrm{~h}$. After cooling down to room temperature, the crude product was filtered over Celite and washed thoroughly with EtOH. The solvent was removed and the solid residue dissolved in $\mathrm{H}_{2} \mathrm{O}$. A sat. aqueous solution of $\mathrm{NH}_{4} \mathrm{PF}_{6}$ was added and the crude product preticipated as a $\mathrm{PF}_{6}$ salt. The solid was collected by centrifugation and washed with Ethanol, Water and $\mathrm{Et}_{2} \mathrm{O}$. The product was isolated via fractionated precipitation from Acetonitrile by adding dropwise $\mathrm{Et}_{2} \mathrm{O}$. The yielded solid was isolated by filtration and washed with pentane. Experimental data fits with the literature. Purity of the sample was assessed by HPLC and elemental analysis. Anal. Calc. for $\mathrm{C}_{31} \mathrm{H}_{22} \mathrm{~F}_{12} \mathrm{~N}_{6} \mathrm{O}_{2} \mathrm{P}_{2} \mathrm{Ru}+0.1 * \mathrm{C}_{5} \mathrm{H}_{12}$ : C 41.63, H 2.57, N 9.25. Found: C 41.84, H 2.68, N 9.56.

$\left[\mathrm{Ru}(\right.$ terpy)$)($ terpy-COOMe) $]\left(\mathrm{PF}_{6}\right)_{2}(\mathbf{6})$

$\mathrm{Ru}\left(\right.$ terpy)Cl 3 (137 mg, $0.31 \mathrm{mmol}, 1.0$ equiv.) and $\mathrm{AgBF}_{4}$ (212 mg, $1.09 \mathrm{mmol}, 3.5$ equiv.) were suspended in Acetone $(50 \mathrm{~mL})$ under nitrogen atmosphere. The mixture was refluxed for $2 \mathrm{~h}$, cooled to room temperature and undissolved solid was filtered off over Celite. The solid was washed with methanol and then the solvent removed under reduced pressure. The residue was dissolved in dry EtOH (50 mL) and 4'-Methylcarboxy-2,2':6',2”-terpyridine (terpyCOOMe) (100 mg, $0.34 \mathrm{mmol}, 1.1$ equiv.) was added. The mixture was heated under reflux for $18 \mathrm{~h}$ under nitrogen atmosphere. The crude product was cooled to room temperature and undissolved solid was filtered off over Celite. The solid was washed with EtOH, the solution concentrated and a sat. aqueous solution of $\mathrm{NH}_{4} \mathrm{PF}_{6}$ was added. The crude product, which precipitated as a $\mathrm{PF}_{6}$ salt was collected by centrifugation and washed with $\mathrm{EtOH}, \mathrm{H}_{2} \mathrm{O}$ and $\mathrm{Et}_{2} \mathrm{O}$. The product was isolated by column chromatography on silica gel with an $\mathrm{CH}_{3} \mathrm{CN} / \mathrm{aq}$. $\mathrm{KNO}_{3}$ $(0.4 \mathrm{M})$ solution $(10: 1)$. The fractions containing the product were united and the solvent was 
removed under reduced pressure. The residue was dissolved in $\mathrm{CH}_{3} \mathrm{CN}$ and undissolved $\mathrm{KNO}_{3}$ was removed by filtration. The solvent was removed again and the product was dissolved in $\mathrm{H}_{2} \mathrm{O}(50 \mathrm{~mL})$. Upon addition of $\mathrm{NH}_{4} \mathrm{PF}_{6}$ the product precipitated as a $\mathrm{PF}_{6}$ salt. The solid was obtained by filtration and was washed three-times with $\mathrm{H}_{2} \mathrm{O}$ and $\mathrm{Et}_{2} \mathrm{O} .154 \mathrm{mg}$ of $[\mathrm{Ru}($ terpy $)($ terpy-COOMe $)]\left(\mathrm{PF}_{6}\right)_{2}(\mathbf{6})(0.17 \mathrm{mmol}, 55 \%)$ were yielded as a red solid. ${ }^{1} \mathrm{H}$ NMR $\left(\mathrm{CD}_{3} \mathrm{CN}, 400 \mathrm{MHz}\right): \delta=9.20(\mathrm{~s}, 2 \mathrm{H}), 8.76(\mathrm{~d}, J=8.2 \mathrm{~Hz}, 2 \mathrm{H}), 8.66-8.62(\mathrm{~m}, 2 \mathrm{H}), 8.50-$ $8.47(\mathrm{~m}, 2 \mathrm{H}), 8.45(\mathrm{t}, J=8.2 \mathrm{~Hz}, 1 \mathrm{H}), 7.98-7.89(\mathrm{~m}, 4 \mathrm{H}), 7.39-7.36(\mathrm{~m}, 2 \mathrm{H}), 7.30-7.27(\mathrm{~m}$, 2H), 7.23-7.19 (m, 2H), 7.16-7.10 (m, 2H), $4.18(\mathrm{~s}, 3 \mathrm{H}) .{ }^{13} \mathrm{C}-\mathrm{NMR}\left(\mathrm{CD}_{3} \mathrm{CN}, 100 \mathrm{MHz}\right): \delta=$ $165.4,158.7,158.4,157.1,155.8,153.5,153.4,139.3,139.1,137.5,137.2,128.8,128.4,125.8$, 125.5, 124.8, 123.7, 54.2. ESI-HRMS m/z: $313.0502[\mathrm{M}]^{2+}$, calcd. for $\mathrm{C}_{32} \mathrm{H}_{24} \mathrm{~N}_{6} \mathrm{O}_{2} \mathrm{Ru}$ 313.0497. Anal. Calc. for $\mathrm{C}_{32} \mathrm{H}_{24} \mathrm{~F}_{12} \mathrm{~N}_{6} \mathrm{O}_{2} \mathrm{P}_{2} \mathrm{Ru}$ : C 41.98, H 2.64, N 9.18. Found: $\mathrm{C} 41.92, \mathrm{H}$ 2.63, N 9.50 .

$\left[\mathrm{Ru}(\right.$ terpy)$)($ terpy-NMe2) $]\left(\mathrm{PF}_{6}\right)_{2}(7)$

$\mathrm{Ru}($ terpy)Cl 3 (205 mg, $0.47 \mathrm{mmol}, \quad 1.0$ equiv.), 4‘-Dimethylamino-2,2’:6',2”-terpyridine (terpy- $\left.\mathrm{NMe}_{2}\right)(141 \mathrm{mg}, 0.52 \mathrm{mmol}, 1.1$ equiv) and some drops of $N$-ethylmorpholine were dissolved in 8:2 EtOH/ $\mathrm{H}_{2} \mathrm{O}(50 \mathrm{~mL})$. The mixture was heated under reflux for $6 \mathrm{~h}$ under nitrogen atmosphere. The crude product was cooled to room temperature and undissolved solid was filtered off over Celite. The solid was washed thoroughly with EtOH and afterwards the solvent was removed under reduced pressure. The residue was dissolved in $\mathrm{H}_{2} \mathrm{O}$ and a sat. aqueous solution of $\mathrm{NH}_{4} \mathrm{PF}_{6}$ was added. The crude product, which precipitated as a $\mathrm{PF}_{6}$ salt was collected by centrifugation and washed with $\mathrm{EtOH}, \mathrm{H}_{2} \mathrm{O}$ and $\mathrm{Et}_{2} \mathrm{O}$. The product was isolated by column chromatography on silica gel with an $\mathrm{CH}_{3} \mathrm{CN} / \mathrm{aq}$. $\mathrm{KNO}_{3}(0.4 \mathrm{M})$ solution (10:1). The fractions containing the product were united and the solvent was removed under reduced pressure. The residue was dissolved in $\mathrm{CH}_{3} \mathrm{CN}$ and undissolved $\mathrm{KNO}_{3}$ was removed 
by filtration. The solvent was removed again and the product was dissolved in $\mathrm{H}_{2} \mathrm{O}(50 \mathrm{~mL})$. Upon addition of $\mathrm{NH}_{4} \mathrm{PF}_{6}$ the product precipitated as a $\mathrm{PF}_{6}$ salt. The solid was obtained by filtration and was washed three-times with $\mathrm{H}_{2} \mathrm{O}$ and $\mathrm{Et}_{2} \mathrm{O}$. The product was isolated via fractionated precipitation from $\mathrm{CH}_{3} \mathrm{CN}$ by adding dropwise $\mathrm{Et}_{2} \mathrm{O} .225 \mathrm{mg}$ of [ $\mathrm{Ru}($ terpy)(terpy$\left.\left.\mathrm{NMe}_{2}\right)\right]\left(\mathrm{PF}_{6}\right)_{2}(7)(0.25 \mathrm{mmol}, 53 \%)$ were yielded as a dark red solid. ${ }^{1} \mathrm{H}-\mathrm{NMR}\left(\mathrm{CD}_{3} \mathrm{CN}, 400\right.$ MHz): $\delta=8.70(\mathrm{~d}, J=8.2 \mathrm{~Hz}, 2 \mathrm{H}), 8.52-8.45(\mathrm{~m}, 4 \mathrm{H}), 8.31(\mathrm{t}, J=8.2 \mathrm{~Hz}, 1 \mathrm{H}), 7.93(\mathrm{~s}, 2 \mathrm{H})$, 7.93-7.82 (m, 4H), 7.50-7.48 (m, 2H), 7.24-7.19 (m, 4H), 7.08-7.03 (m, 2H), 3.46 (s, 6H). ${ }^{13} \mathrm{C}-$ NMR (CD $\left.{ }_{3} \mathrm{CN}, 100 \mathrm{MHz}\right): \delta=159.9,159.4,157.3,156.3,154.8,153.5,152.9,138.6,138.5$, 135.2, 128.3, 127.7, 125.0, 124.7, 124.3, 107.4, 40.8. ESI-HRMS m/z: $305.5687[\mathrm{M}]^{2+}$, calcd. for $\mathrm{C}_{32} \mathrm{H}_{27} \mathrm{~N}_{7} \mathrm{Ru}$ 305.5680. Anal. Calc. for $\mathrm{C}_{32} \mathrm{H}_{27} \mathrm{~F}_{12} \mathrm{~N}_{7} \mathrm{P}_{2} \mathrm{Ru}$ : C 42.68, H 3.02, N 10.89. Found: C 42.55, H 2.95, N 10.82.

\subsection{X-ray crystallography}

X-ray single-crystal data were collected at 160(1) K with Oxford liquid-nitrogen Cryostream coolers on Rigaku OD diffractometers: SuperNova (CCD Atlas detector) for 1_BPh $\mathbf{1}$ and XtaLAB Synergy Dualflex (Pilatus 200K detector) for all the other X-ray analyses. Single wavelength X-ray sources from micro-focus sealed X-ray tubes were used with the Mo $\mathrm{K}_{\alpha}$ radiation $(\lambda=0.71073 \AA)[46]$ for $\mathbf{1}_{-} \mathbf{B P h}_{4}$ and $\mathbf{2}_{-} \mathbf{B P h}_{\mathbf{4}}$ and with the $\mathrm{Cu} \mathrm{K}_{\alpha}$ radiation $(\lambda=$ $1.54184 \AA$ ) $[46]$ for all other analyses. The selected single crystals were mounted using polybutene oil on a flexible loop fixed on a goniometer head and transferred to the diffractometer. Pre-experiments, data collections, data reductions and analytical absorption corrections[47] were performed with the program suite CrysAlisPro[48]. Using Olex2,[49] all structures were solved with the SHELXT[50] small molecule structure solution program and refined with the SHELXL2018/3 program package[51] by full-matrix least-squares minimization on $\mathrm{F}^{2}$. Molecular graphics were generated using Mercury 4.0.[52] The crystal 
data collections and structure refinement parameters for are summarized in Tables S1 - S9. CCDC 1889454 (for 2_PF 6 ), 1889455 (for 2_BF 4), 1889456 (for 3_BF 4 ), 1889457 (for 3_PF 6 ), 1889458 (for 4_BF 4 ), 1889459 (for 2_BPh4), 1889460 (for 4_PF $), 1889461$ (for 6_BPh4), 1889462 (for 6_PF $), 1889463$ (for 6_BF 4 ), 1889464 (for 5_BPh4), 1889465 (for 7_PF 6 ), 1889466 (for terpy-Br), 1889467 (for 7_BF 4 ), 1889468 (for 5_BF 4 ), 1889469 (for terpy-CI) and 1889470 (for $\mathbf{1} \mathbf{B P h}_{4}$ ) contain the supplementary crystallographic data for these compounds, and can be obtained free of charge from the Cambridge Crystallographic Data Centre via www.ccdc.cam.ac.uk/data_request/cif.

\subsection{Spectroscopic measurements}

The absorption of the samples has been measured with a SpectraMax M2 Spectrometer (Molecular Devices). The emission was measured by irradiation of the sample in fluorescence quartz cuvettes (width $1 \mathrm{~cm}$ ) using a NT342B Nd-YAG pumped optical parametric oscillator (Ekspla) at $450 \mathrm{~nm}$. Luminescence was focused and collected at right angle to the excitation pathway and directed to a Princeton Instruments Acton SP-2300i monochromator. As a detector a PI-Max 4 CCD camera (Princeton Instruments) has been used.

\subsection{Luminescence quantum yield measurements}

For the determination of the luminescence quantum yield, the samples were prepared in a nondegassed $\mathrm{CH}_{3} \mathrm{CN}$ solution with an absorbance of 0.1 at $450 \mathrm{~nm}$. This solution was irradiated in fluorescence quartz cuvettes (width $1 \mathrm{~cm}$ ) using a NT342B Nd-YAG pumped optical parametric oscillator (Ekspla) at $450 \mathrm{~nm}$. The emission signal was focused and collected at right angle to the excitation pathway and directed to a Princeton Instruments Acton SP-2300i monochromator. As a detector a PI-Max 4 CCD camera (Princeton Instruments) has been used. 
The luminescence quantum yields were determined by comparison with the reference $\left.[\mathrm{Ru} \text { (bipy) })_{3}\right] \mathrm{Cl}_{2}$ in $\mathrm{CH}_{3} \mathrm{CN}\left(\Phi_{\mathrm{em}}=0.059\right)[53]$ applying the following formula :

$$
\begin{gathered}
\Phi_{\mathrm{em}, \text { sample }}=\Phi_{\mathrm{em}, \text { reference }} *\left(\mathrm{~F}_{\text {reference }} / \mathrm{F}_{\text {sample }}\right) *\left(\mathrm{I}_{\text {sample }} / \mathrm{I}_{\text {reference }}\right) *\left(\mathrm{n}_{\text {sample }} / \mathrm{n}_{\text {reference }}\right)^{2} \\
\mathrm{~F}=1-10^{-\mathrm{A}}
\end{gathered}
$$

$\Phi_{\mathrm{em}}=$ luminescence quantum yield, $\mathrm{F}=$ fraction of light absorbed, $\mathrm{I}=$ integrated emission intensities, $\mathrm{n}=$ refractive index, $\mathrm{A}=$ absorbance of the sample at irradiation wavelength.

\subsection{Lifetime measurements}

For the determination of the lifetimes, the samples were prepared in an air saturated and in a degassed $\mathrm{CH}_{3} \mathrm{CN}$ solution with an absorbance of 0.1 at $450 \mathrm{~nm}$. This solution was irradiated in fluorescence quartz cuvettes (width $1 \mathrm{~cm}$ ) using a NT342B Nd-YAG pumped optical parametric oscillator (Ekspla) at $450 \mathrm{~nm}$. The emission signal was focused and collected at right angle to the excitation pathway and directed to a Princeton Instruments Acton SP-2300i monochromator. As a detector a R928 photomultiplier tube (Hamamatsu) has been used.

\subsection{Distribution coefficient}

The lipophilicity of a compound was determined by measuring its distribution coefficient between the PBS and octanol phase by using the "shake-flask" method. For this technique, the used phases were previously saturated in each other. The compound was dissolved in the phase (A) with its major presence with an absorbance of about 0.5 at $450 \mathrm{~nm}$. This solution was then mixed with an equal volume of the other phase (B) at $80 \mathrm{rpm}$ for $8 \mathrm{~h}$ with an Invitrogen sample mixer and equilibrated overnight. The phase A was then carefully separated from phase B. The amount of the compound before and after the sample mixing was determined by UV/VIS spectroscopy at $450 \mathrm{~nm}$ with a SpectraMax M2 Microplate Reader (Molecular Devices). The 
evaluation of the complexes was repeated three times and the ratio between the organic and aqueous phase calculated.

\subsection{Stability in human plasma}

The stability of the complexes was evaluated with caffeine as an internal standard, which has already shown to be suitable for these experiments.[54] The pooled human plasma was obtained from Biowest and caffeine from TCI Chemicals. Stock solutions of the compounds and caffeine were prepared in DMSO. One aliquot of the solutions was added to $975 \mu \mathrm{L}$ of human plasma to a total volume of $1000 \mu \mathrm{L}$. Final concentrations of the compounds of $50 \mu \mathrm{M}$ and caffeine of $25 \mu \mathrm{M}$ were achieved. The resulting solution was incubated for $48 \mathrm{~h}$ at $37{ }^{\circ} \mathrm{C}$ with continuous gentle shaking (ca. $300 \mathrm{rpm}$ ). The reaction was stopped after the incubation time by addition of $4 \mathrm{~mL}$ of methanol. The mixture was centrifuged for $45 \mathrm{~min}$ at $650 \mathrm{~g}$ at $4{ }^{\circ} \mathrm{C}$. The methanolic solution was filtered through a $0.2 \mu \mathrm{m}$ membrane filter. The solvent was evaporated under reduced pressure and the residue was dissolved in $1: 1(\mathrm{v} / \mathrm{v}) \mathrm{CH}_{3} \mathrm{CN} / \mathrm{H}_{2} \mathrm{O} 0.1 \%$ TFA solution. The solution was filtered through a $0.2 \mu \mathrm{m}$ membrane filter and analysed using a 1260 Infinity HPLC System (Agilent Technology). A Pursuit XRs 5 C18 (250x4.6 mm) reverse phase column has been used and the absorption at $250 \mathrm{~nm}$ measured. The samples have been measured with a flow rate of $1 \mathrm{~mL} / \mathrm{min}$ and a linear gradient of $0.1 \%$ TFA containing $\mathrm{H}_{2} \mathrm{O}$ and $\mathrm{CH}_{3} \mathrm{CN}(\mathrm{t}=0$ $3 \min 95 \% \mathrm{H}_{2} \mathrm{O} 0.1 \%$ TFA, $5 \% \mathrm{CH}_{3} \mathrm{CN} ; \mathrm{t}=17 \min 100 \% \mathrm{CH}_{3} \mathrm{CN} ; \mathrm{t}=23 \min 100 \% \mathrm{CH}_{3} \mathrm{CN}$ ) has been used.

\subsection{Photostability}

The samples were prepared in an air saturated $\mathrm{CH}_{3} \mathrm{CN}$ solution. To measure the photostability, the samples were irradiated at $450 \mathrm{~nm}$ (light dose after $10 \mathrm{~min}: 13.22 \mathrm{~J} / \mathrm{cm}^{2}$ ) in 96 well plates with an Atlas Photonics LUMOS BIO irradiator during time intervals from 0-10 min. The 
absorbance spectrum from 350-700 $\mathrm{nm}$ was recorded with an SpectraMax M2 Microplate Reader (Molecular Devices) after each time interval and compared. As a positive control $\left[\mathrm{Ru}\right.$ (bipy) $\left.{ }_{3}\right] \mathrm{Cl}_{2}$ and as a negative control Protoporphyrin IX has been used.

\subsection{Cell culture}

HeLa cells were cultured in DMEM medium supplemented with $10 \%$ fetal calf serum. RPE-1 cells were cultured in DMEM/F-12 medium supplemented with $10 \%$ fetal calf serum. Cell lines were complemented with $100 \mathrm{U} / \mathrm{ml}$ penicillin-streptomycin mixture, and maintained in humidified atmosphere at $37^{\circ} \mathrm{C}$ and $5 \%$ of $\mathrm{CO}_{2}$. Before an experiment, cells were passaged three times.

\subsection{2. (Photo-)Cytotoxicity}

The cytotoxicity of the compounds was accessed by measuring the cell viability using a fluorometric resazurin assay. Cells were seeded in triplicates in 96 well plates (4000 cells per well in $100 \mu \mathrm{L}$ of media). After $24 \mathrm{~h}$, media was removed and the cells were treated with increasing concentrations of the compounds diluted in cell media achieving a total volume of $200 \mu \mathrm{L}$. The cells were incubated with the compounds for $4 \mathrm{~h}$. After this time, the media was removed and replaced with $200 \mu \mathrm{L}$ of fresh media. For the phototoxicity studies, the cells were exposed to light with an Atlas Photonics LUMOS BIO irradiator. Each well was constantly illuminated with $480 \mathrm{~nm}$ irradiation. During this time, the temperature was maintained at 37 ${ }^{\circ} \mathrm{C}$. The cells were grown in the incubator for additional $44 \mathrm{~h}$. For the determination of the dark cytotoxicity, the cells were not irradiated and after the media exchange directly incubated for $44 \mathrm{~h}$. After this time, media was replaced with fresh media containing resazurin with a final concentration of $0.2 \mathrm{mg} / \mathrm{mL}$. After $4 \mathrm{~h}$ incubation, the amount of the fluorescent product resorufin was determined upon excitation at $540 \mathrm{~nm}$ and measurement its emission at $590 \mathrm{~nm}$ using a SpectraMax M2 Microplate Reader (Molecular Devices). The obtained data was analysed with the GraphPad Prism software. 


\section{Results and Discussion}

\subsection{Syntheses and Characterisation}

$\mathrm{Ru}(\mathrm{II})$ complexes 1-7 investigated in this work can be visualised in Figure 1. The synthesis and characterisation of compounds $\mathbf{1},[42] \mathbf{2},[43] \mathbf{3}[44]$ and $\mathbf{5}[45]$ have been previously reported in the literature. However, in this work, except for 1, a different synthetic procedure was employed to prepare them. To the best of our knowledge, complexes 4, 6 and 7 have never been reported. Specifically, the substituted 2,2':6',2'-terpyridine ligands (terpy-X, Scheme S1), namely 4'chloro-2,2’:6',2”-terpyridine (terpy-Cl),[37] 4'-bromo-2,2':6',2”-terpyridine (terpy-Br),[38] 4'-methoxy-2,2':6',2”-terpyridine (terpy-OMe),[39] 4'-carboxy-2,2':6',2”-terpyridine (terpy$\mathrm{COOH}),[40] \quad 4^{\prime}$-methylcarboxy-2,2':6',2"-terpyridine (terpy-COOMe)[40] and 4'dimethylamino-2,2':6',2"-terpyridine (terpy-NMe 2 )[41] were synthesised as previously reported. Analytical data of all synthesised ligands matched with those of the literature. Interestingly, the structures of the ligands terpy- $\mathrm{Cl}$ and terpy- $\mathrm{Br}$ were confirmed by single crystal X-ray crystallography in this work (see section below). Complexes were synthesised by refluxing the precursor $\mathrm{Ru}\left(\right.$ terpy) $\mathrm{Cl}_{3}[36]$ and the respective terpy ligand in ethanol to give complexes 1-7 (Scheme S2) in moderate yields.[36] Worthy of note, the reaction between $\mathrm{Ru}$ (terpy) $\mathrm{Cl}_{3}$ with terpy-COOMe yielded a mixture of different undesired products, as observed by HPLC (data not shown). To overcome this problem, the synthetic procedure was changed to a two-step reaction. In the first step, the $\mathrm{Cl}$ substituents on the $\mathrm{Ru}(\mathrm{II})$ core were exchanged with solvent molecules by reaction of $\mathrm{Ru}$ (terpy) $\mathrm{Cl}_{3}$ with $\mathrm{AgBF}_{4}$ and filtration of the formed $\mathrm{AgCl}$. In the second step, the terpy-COOMe ligand was coordinated to the metal core upon replacement of the solvent molecules. All complexes were analysed by ${ }^{1} \mathrm{H},{ }^{13} \mathrm{C}-\mathrm{NMR}$, ESIHRMS as well elemental analysis (Figure S1-S9). Worthy of note, the structures of all Ru(II) 
complexes prepared in this work were determined by single crystal X-ray crystallography (see below).

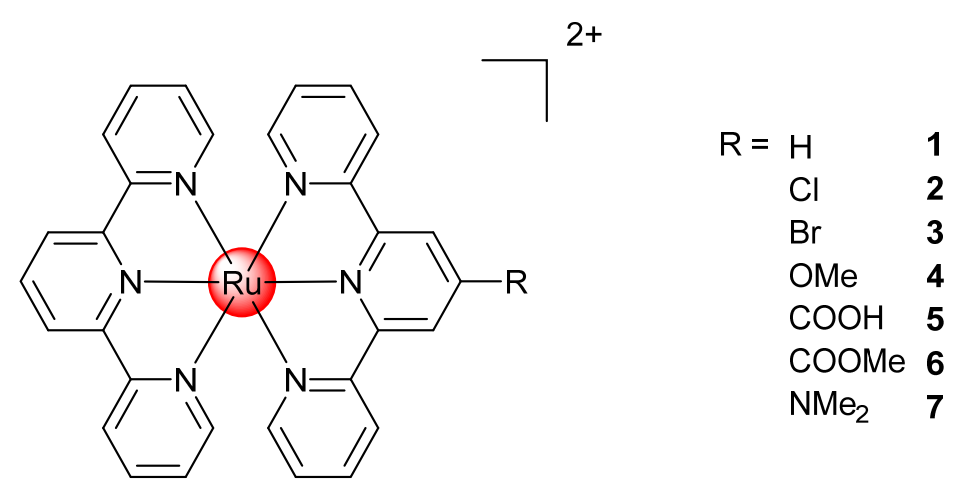

Figure 1. Chemical structures of the $\left[\mathrm{Ru}(\text { terpy)(terpy-X) }]^{2+}\right.$ complexes investigated in this work. The complexes were isolated as $\mathrm{PF}_{6}$ salts.

\subsection{X-ray crystallography}

The crystal structures of terpy-Cl, terpy-Br, and all investigated $\left[\mathrm{Ru}(\text { terpy)(terpy-X) }]^{2+}\right.$ complexes $\mathbf{1}$ - $\mathbf{7}$ have been determined by single crystal X-ray diffraction studies. Crystal data, structure refinement parameters and molecular structures are presented in Tables S1 - S9 and Figures $\mathrm{S} 10-\mathrm{S} 18$. In the literature, the $\left[\mathrm{Ru}(\text { terpy })_{2}\right]^{2+}$ cation is well known and can be found in many crystal structures co-crystallizing with various counterions $\left(\mathrm{Cl}^{-}, \mathrm{I}, \mathrm{BF}_{4}^{-}, \mathrm{ClO}_{4}^{-}, \mathrm{PF}_{6}^{-}\right.$and other Pt anionic clusters...) and solvent molecules $\left(\mathrm{H}_{2} \mathrm{O}, \mathrm{CH}_{2} \mathrm{Cl}_{2}, \mathrm{MeCN}, \mathrm{NMe}_{2} \mathrm{CHO} \ldots\right)$.[42, 55-63] There is also a very large number of other ruthenium terpyridine complexes in the Cambridge Structural Database (version 5.40, last update November 2018).[64] For instance, 142 structures were obtained from a search with terpyridine ligands substituted in para position. In the crystal structures of our new metal complexes, the $\mathrm{Ru}(\mathrm{II})$ centres are typically in a distorted octahedral environment coordinated by two terpyridine ligands acting as tridentate pincer ligands through the nitrogen atoms. The two ligand planes are always exactly or almost perpendicular to each other. The largest deviation to orthogonality is observed in $\mathbf{6}$ _PF 6 with 
an angle of $86.9(3)^{\circ}$ between the calculated mean planes. As a structural feature, the $\mathrm{M}-\mathrm{N}_{\text {central }}$ distances are significantly shorter than the $\mathrm{M}-\mathrm{N}_{\text {terminal }}$ distances which is typical for coordination of conjugated terimine systems. The $\mathrm{M}-\mathrm{N}_{\text {central }}$ distances fall in the range 1.973(3) $-1.998(3) \AA$ and the $\mathrm{M}-\mathrm{N}_{\text {terminal }}$ distances in the range 2.063(2) - 2.089(9) $\AA$. In most of the crystal structures of $\mathbf{2}-\mathbf{7}$, the $\mathrm{Ru}(\mathrm{II})$ molecules exhibit a positional disorder of the terpyridine ligands. The result of such a disorder is that the group or atom in para position on the central pyridine of the substituted terpyridine ligand (and consequently the corresponding $\mathrm{H}$ atom of the unsubstituted ligand as well) appears on both terpyridine ligands with a site-occupancy factor of 0.5. It is observed in nine crystal structures over fourteen, only $\mathbf{4} \_\mathbf{P F}_{\mathbf{6}}, \mathbf{5} \_\mathbf{B F}_{\mathbf{4}}, \mathbf{6} \_\mathbf{P F}_{\mathbf{6}}$, 7_PF 6 and 7_BF 4 are free of that kind of disorder. It seems to not be influenced or controlled by the presence of one specific counter ion, neither by the para substituent but it is worth noting that when the latter is a "mono-atomic" group like in complexes $\mathbf{2}$ and $\mathbf{3}(\mathrm{X}=\mathrm{Cl}, \mathrm{Br})$ the disorder is always observed (five crystal structures). The crystal packing of [M(terpy)2] cations have been fully analysed by Scudder et al. in 1999.[65] A standard crystal supramolecular motif has been identified as a two-dimensional net of terpy embraces involving molecules attracted by faceto-face $\pi \ldots \pi$ interactions and edge-to-face C-H... $\pi$ interactions between the external rings of the ligands. Despite the para substitution of one of the terpyridine ligands, this standard "terpy embrace" motif can be observed in six of our crystal structures: $\mathbf{2}_{-} \mathbf{B F}_{4}, \mathbf{2} \mathbf{P F}_{6}, \mathbf{3} \mathbf{B F}_{4}, \mathbf{3} \mathbf{P F}_{6}, \mathbf{4} \mathbf{B F}_{\mathbf{4}}$ and 7_BF 4 (Figure S19). The presence of the bulky BPh $4{ }^{-}$couterion in $\mathbf{1}_{-} \mathbf{B P h}_{4}, \mathbf{2}_{-} \mathbf{B P h}_{4}, \mathbf{5} \mathbf{B P h}_{4}$ and 6_BPh 4 rules out that standard layer structure since no direct interactions are observed between cations anymore, the crystal packing is mainly governed by $\pi . . . \pi$ interactions between the pyridine rings of the cations and the phenyl rings of the anions (Figure S20). The so-called terpy embrace motif still exists in the other crystal structures but the typical face-to-face and edge-to-face interactions only lead to chains in $\mathbf{5} \mathbf{B F}_{\mathbf{4}}$ and $\mathbf{7} \mathbf{P F}_{\mathbf{6}}$ (Figure S21) or form small units of two molecules in $\mathbf{6} \_\mathbf{P F}_{\mathbf{6}}$ or four molecules in $\mathbf{6} \_\mathbf{B F}_{\mathbf{4}}$ (Figure S22). These chains or units are further 
connected to via $\mathrm{C}-\mathrm{H} . . . \mathrm{O}$ hydrogen bondings or $\mathrm{C}-\mathrm{H} \ldots \pi$ interactions, and to the counterions via $\mathrm{C}$ H...F interactions to form a three-dimensional network. Finally, the crystal structure of $\mathbf{4} \mathbf{P F}_{\mathbf{6}}$ is the only one to not exhibit $\pi \ldots \pi$ interactions, only C-H... $\pi$ and C-H...F interactions are observed.

\subsection{Photophysical Characterisation}

For a complete characterisation, the absorption and emission properties of the synthesised compounds were investigated. The $\mathrm{UV} / \mathrm{V}$ is absorption spectra were recorded in $\mathrm{CH}_{3} \mathrm{CN}$ (Figure 2) and PBS buffer (Figure S23). The comparison between the different complexes shows that the para substituents on the central pyridine of the terpy ligand influences the amount of light absorbed and therefore the excitation coefficient (Table S10). However, no strong shift either to blue or red could be observed. The analysis of the absorption shows that the very intensive band in the UV region is caused by a ligand centred (LC) $\pi-\pi^{*}$ transition. The other broad band in the visible spectrum $(\sim 400-550 \mathrm{~nm})$ was attributed to the spin-allowed $\mathrm{d}-\pi$ metal-to-ligand charge transfer (MLCT) transition.[20, 25, 66] Next to the absorption, the emission of the complexes was investigated. The synthesised complexes have a very weak emission from $\sim 550$ $800 \mathrm{~nm}$ (Table S1, Figure S24) upon excitation in $\mathrm{CH}_{3} \mathrm{CN}$ at $450 \mathrm{~nm}$ at room temperature which was measurable only at the detection limit of our used setup. The luminescence quantum yields were found to be $<0.01 \%$ in $\mathrm{CH}_{3} \mathrm{CN}$ which is fitting with previous studies of similar complexes.[30, 67-69] For verification that the measured emission is caused by the compounds, the excitation and absorption spectrum of compound $\mathbf{6}$ has been compared. As expected, no significant differences between the spectra could be observed. The characterisation of the excited state lifetimes was not possible with our apparatus due to a necessary minimal delay between excitation and detection, indicating that the compounds 1-7 have lifetimes $<29 \mathrm{~ns}$. Therefore, as expected, the excited state lifetimes are in the same range than other $\left[\mathrm{Ru}(\text { terpy })_{2}\right]^{2+}$ derivatives previously published.[30, 67-69] 


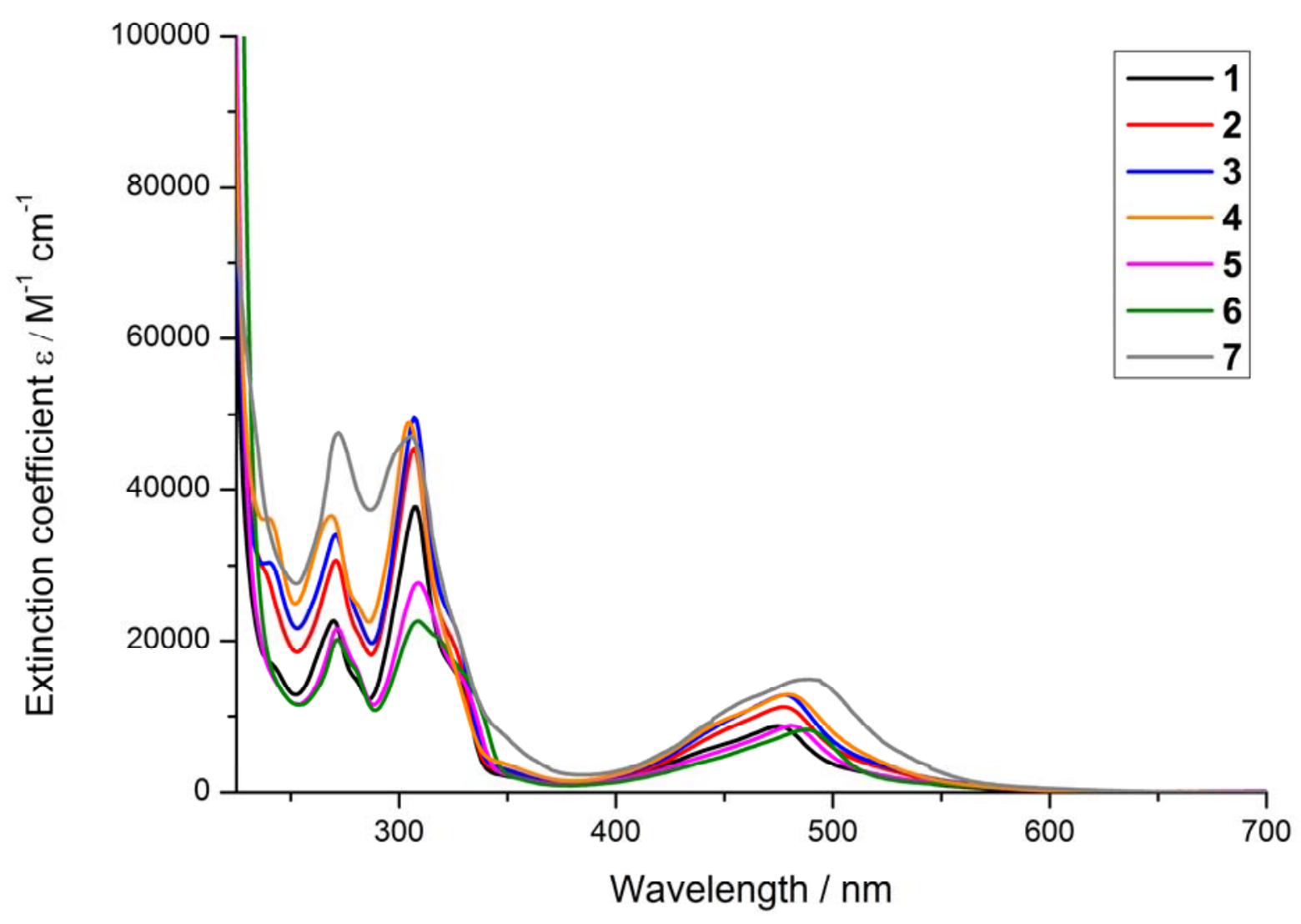

Figure 2. UV/Vis spectra of the complexes 1-7 in $\mathrm{CH}_{3} \mathrm{CN}$.

\subsection{Determination of the $\log P$ values}

After having assessed the photophysical properties of our compounds, we investigated their solubility in an aqueous solution which is crucial for any kind of biological application. For this purpose, we determined the distribution coefficient ( $\log P$ values) of the complexes between an aqueous PBS phase and a lipophilic octanol phase by the "shake-flask" method, as previously performed by our group with other metal complexes.[70, 71] All compounds were mostly found in the aqueous phase, which we assume, is due to the positive charge of the metal complexes. As anticipated, the results (Figure 3) show that the $\log P$ values change based on the functional group present on the terpy ligand. Compound $\mathbf{5}$ bearing a carboxylic acid was found to be the most hydrophilic and complex 3 bearing a bromine substituent the most lipophilic one. The 
following order could be made (from the most hydrophilic to the most lipophilic): $\mathbf{5}>\mathbf{1}>\mathbf{6}>$ $2>4>7>3$.

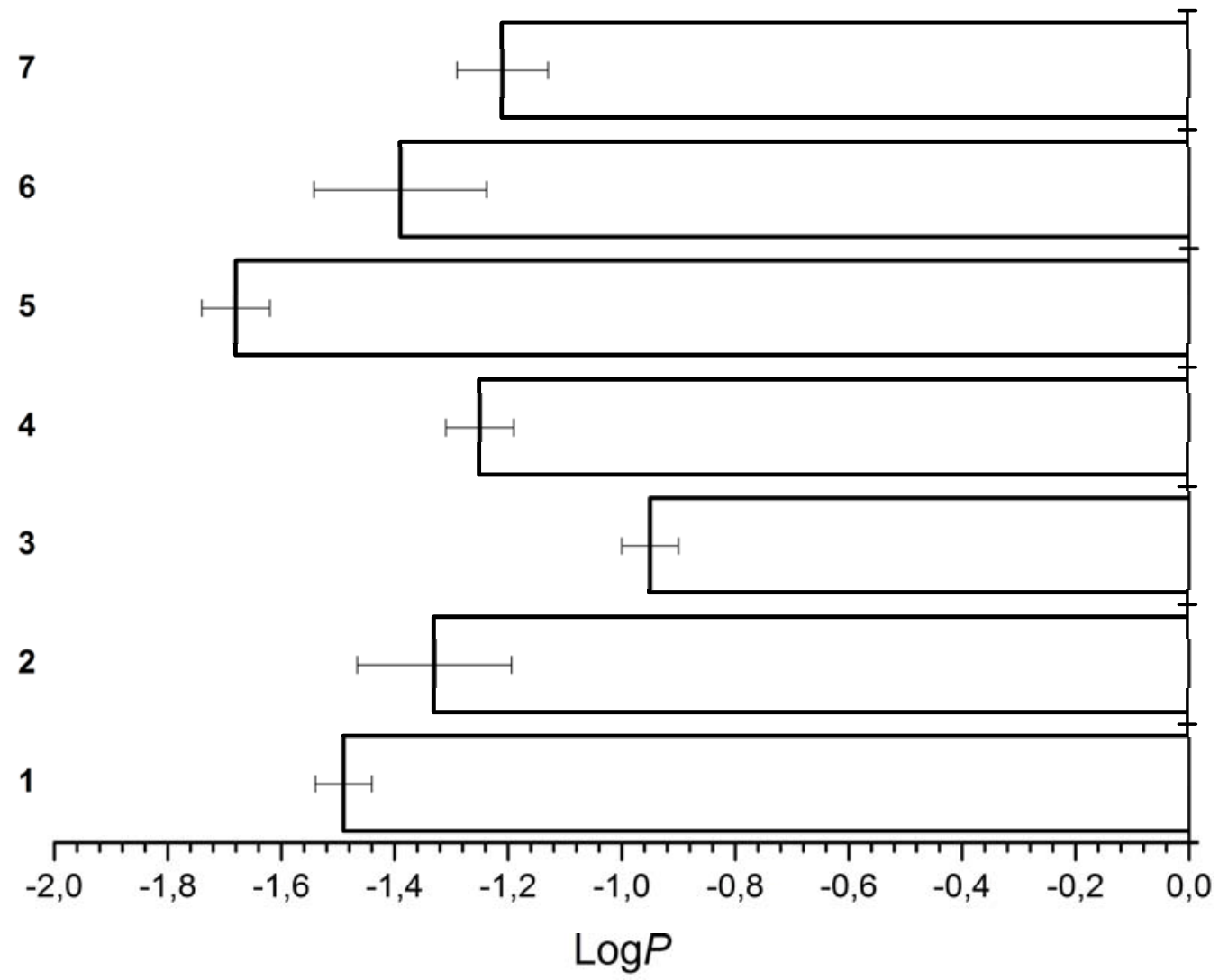

Figure 3. Distribution coefficients ( $\log P$ values) of complexes 1-7.

\subsection{Stability in Human Plasma}

In order to have a preliminary insight of the metabolic stability of our compounds, their compatibility under biological conditions was investigated. For this purpose, the complexes were incubated upon the addition of the internal standard caffeine in human plasma at $37{ }^{\circ} \mathrm{C}$ for $48 \mathrm{~h}$ and their stability investigated, as previously performed by our group with other metal complexes.[21, 23] After extraction from the plasma, the complexes were analysed via HPLC and the chromatogram before and after incubation compared. Complexes 1-5 and 7 (Figure S25-S29, S31) were found to be stable for a therapeutically relevant time. However, some degradation of compound 6 (Figure S30) was observed, as indicated by the appearance of small peaks as well as a decreased of the compound/caffeine ratio. 


\subsection{Photostability}

Since $\mathrm{Ru}(\mathrm{II})$ complexes are well known to act as PDT PSs, the compounds were investigated to assess if a phototobleaching effect, which is a degradation of the compound upon light irradition, was observed.[72, 73] To investigate this, the complexes were constantly irradiated at $450 \mathrm{~nm}$ in $\mathrm{CH}_{3} \mathrm{CN}$ and the potential change in absorbance between $350-700 \mathrm{~nm}$ from $0-10$ min monitored. As a positive control, $\left[\mathrm{Ru}(\text { bipy })_{3}\right] \mathrm{Cl}_{2}[74]$ (Figure $\mathrm{S} 32$ ) and as a negative control Protoporphyrin IX (PpIX)[75] (Figure S33) were chosen. Analyses (Figure S34-S40) shows a different photostability of the complexes based on the functional group they bear. In general, a rather small photobleaching effect was observed. From comparison between the different complexes, the following order for photostability can be made from the most photostable to the least photostable: $\mathbf{2} \sim \mathbf{3}>\mathbf{4}>\mathbf{1}>\mathbf{7}>\mathbf{5}>\mathbf{6}$.

\subsection{Dark Cytotoxicity and (Photo-)toxicity}

We then investigated the biological influence of the complexes 1-7, their corresponding ligands and precursor on non-cancerous retinal pigment epithelium (RPE-1) and human cervical carcinoma (HeLa) cells. For this purpose, cells were treated with the compounds in the dark as well as upon light irradiation at $480 \mathrm{~nm}$ and their cell viability measured using a fluorometric resazurin assay. The $\mathrm{IC}_{50}$ values of the compounds are shown in Table 1. Unfortunantly, complexes 1-6 did not show a measurable cytotoxic effect in HeLa cells in the dark as well as upon light irradition. The poor phototoxic effect was expected due to the poor photophysical properties including the short excited state lifetimes of our complexes. However, compound 7 was found to be cytotoxic in the micromolar range in RPE-1 and HeLa cells. Unfortunately, no selectivity for cancerous cells versus non-cancerous cells was observed. The $\mathrm{IC}_{50}$ values for 7 are 1.4 times higher in RPE-1 and 3.3 times higher in HeLa cells than for the clincally used 
drug cisplatin. In terms of PDT treatement, an important value for the evaluation of a PS is the comparison between a dark and light treatment. For this purpose, the phototoxic index (PI) is defined as the ratio between the $\mathrm{IC}_{50}$ value in the dark and upon irradiation. Compound 7 was found to be phototoxic with a PI value of 1.4 in RPE-1 and HeLa cells. These values are rather low in comparison to porphyrin based-PSs like Protoporhyrin IX (PpIX). Additionally, the cytotoxic effects of the differently substituted terpy ligands were investigated (Table 1) in the dark as well as upon light exposure. Contrary to the cytotoxicty of the complexes, all the ligands except of terpy-COOH and terpy-COOMe were toxic in the mircomolar range. The exposure ot light revealed phototoxcity with PI values in the range 1.0 - 2.0. Terpy ligands are well known to bind to biological relevant metals as for example $\mathrm{Cu}$ (II) inside of cells or living organisms and therfore their properties have been investigated as imaging probes and potential anticancer agents.[76, 77] As the terpy ligands itself are not able to cause such a phototoxic effect, we assume that they could potentially bind with a biological relevant metal ion and the resulting complex could cause this effect.

Table 1. IC 50 values in the dark and upon irradiation at $480 \mathrm{~nm}$ for the complexes 1-7, the terpy$\mathrm{X}$ ligands and the Ru-precursor incubated in non-cancerous retinal pigment epithelium (RPE1) and human cervical carcinoma (HeLa) cells. Average of three independent measurements.

\begin{tabular}{|c|c|c|c|c|c|c|}
\hline & \multicolumn{3}{|c|}{ RPE-1 } & \multicolumn{3}{|c|}{ HeLa } \\
\hline Compound & $\begin{array}{c}\mathrm{IC}_{50} / \boldsymbol{\mu M} \\
\text { dark }\end{array}$ & $\begin{array}{c}\mathrm{IC}_{50} / \mu \mathrm{M} \\
480 \mathrm{~nm} \\
(10 \mathrm{~min}, \\
\left.3.1 \mathrm{~J} / \mathrm{cm}^{2}\right)\end{array}$ & PI & $\begin{array}{c}\mathrm{IC}_{50} / \mu \mathrm{M} \\
\text { dark }\end{array}$ & $\begin{array}{c}\mathrm{IC}_{50} / \mu \mathrm{M} \\
480 \mathrm{~nm} \\
(10 \mathrm{~min}, \\
\left.3.1 \mathrm{~J} / \mathrm{cm}^{2}\right)\end{array}$ & PI \\
\hline 1 & $>100$ & $>100$ & n.d. & $>100$ & $>100$ & n.d. \\
\hline 2 & $>100$ & $>100$ & n.d. & $>100$ & $>100$ & n.d. \\
\hline
\end{tabular}




\begin{tabular}{|c|c|c|c|c|c|c|}
\hline 3 & $>100$ & $>100$ & n.d. & $>100$ & $>100$ & n.d. \\
\hline 4 & $>100$ & $>100$ & n.d. & $>100$ & $>100$ & n.d. \\
\hline 5 & $>100$ & $>100$ & n.d. & $>100$ & $>100$ & n.d. \\
\hline 6 & $>100$ & $>100$ & n.d. & $>100$ & $>100$ & n.d. \\
\hline 7 & $39.7 \pm 3.6$ & $27.5 \pm 1.1$ & 1.4 & $35.1 \pm 0.6$ & $24.5 \pm 2.6$ & 1.4 \\
\hline terpy-H & $21.8 \pm 0.7$ & $21.9 \pm 2.4$ & 1.0 & $26.5 \pm 3.0$ & $18.1 \pm 0.7$ & 1.5 \\
\hline terpy-Cl & $8.7 \pm 0.8$ & $8.4 \pm 1.2$ & 1.0 & $12.3 \pm 0.6$ & $8.3 \pm 1.3$ & 1.5 \\
\hline terpy-Br & $10.5 \pm 0.4$ & $8.8 \pm 0.3$ & 1.2 & $13.7 \pm 3.2$ & $6.9 \pm 0.1$ & 2.0 \\
\hline terpy-OMe & $18.9 \pm 0.8$ & $16.7 \pm 0.7$ & 1.1 & $40.9 \pm 2.1$ & $40.2 \pm 0.3$ & 1.0 \\
\hline $\begin{array}{l}\text { terpy- } \\
\text { COOH }\end{array}$ & $>100$ & $>100$ & n.d. & $50.5 \pm 9.1$ & $37.5 \pm 5.4$ & 1.3 \\
\hline $\begin{array}{c}\text { terpy- } \\
\text { COOMe }\end{array}$ & $>100$ & $>100$ & n.d. & $23.3 \pm 4.0$ & $20.0 \pm 2.4$ & 1.2 \\
\hline terpy-NMe 2 & $14.8 \pm 1.4$ & $13.3 \pm 2.2$ & 1.1 & $19.6 \pm 1.3$ & $17.7 \pm 2.7$ & 1.1 \\
\hline $\mathrm{Ru}(\mathrm{Terpy}) \mathrm{Cl}_{3}$ & $>100$ & $>100$ & n.d & $96.0 \pm 3.5$ & $87.5 \pm 8.0$ & 1.1 \\
\hline PpIX & $>100$ & $3.8 \pm 0.1$ & $>26$ & $>100$ & $2.5 \pm 0.1$ & $>40$ \\
\hline Cisplatin & $29.3 \pm 1.4$ & - & - & $10.5 \pm 0.8$ & - & - \\
\hline
\end{tabular}

n.d. $=$ not determinable . 


\section{Conclusion}

In this study, we report on the systematic investigation of differently substituted $\left[\mathrm{Ru}(\right.$ terpy $)(\text { terpy-X) }]^{2+}\left(\mathrm{X}=\mathrm{H}(\mathbf{1}), \mathrm{Cl}(\mathbf{2}), \mathrm{Br}(\mathbf{3}), \mathrm{OMe}(\mathbf{4}), \mathrm{COOH}(\mathbf{5}), \mathrm{COOMe}(\mathbf{6}), \mathrm{NMe}_{2}\right.$ (7)) complexes as potential chemotherapeutic agents and PDT PSs. The compounds were characterized in-depth including by single crystal X-ray crystallography. Photophysical measurements showed that the complexes strongly absorb in the green region of the visible electromagnetic spectrum. Further analysis revealed that they are weakly luminescent and have a short lived excited state. Despite their unfavourable photophysical properties such as a weak emission and short lifetimes, ruthenium terpyridine complexes were found in the past to be able to bind to DNA and to cleave it upon light irradiation. Inspired by the works of Thorp and Brewer et al., we systematically evaluated their potential as PDT PSs. The distribution coefficient ( $\log P$ value) of the complexes between an aqueous PBS phase and a lipophilic octanol phase was determined. As expected, all compounds were majorly found in the aqueous phase. Importantly, compounds 1-5 and 7 were found to be stable in human plasma and to have only a small photobleaching effect upon continuous LED irradiation. Complex $\mathbf{6}$ was found to be not stable in human plasma. Biological evaluation on one cancerous and one non-cancerous cell line demonstrated that compounds 1-6 had no cytotoxic effect in the dark as well as upon light irradiation. In comparison, 7 was found to have a dark and (photo-)cytotoxicity in the micromolar range. However, irradiation at $480 \mathrm{~nm}$ seems to have only a negligible effect. We assume this is caused by the very short excited state lifetimes of this complex. Overall, this study demonstrates that small structural changes are able to influence significantly the effect that a compound has on cell viability. 


\section{Acknowledgements}

This work was financially supported by an ERC Consolidator Grant PhotoMedMet to G.G. (GA 681679) and has received support under the program "Investissements d' Avenir" launched by the French Government and implemented by the ANR with the reference ANR-10-IDEX-000102 PSL (G.G.). 


\section{References}

[1] D. Cella, E. Cherin, Compr. Ther., vol. 14, 1988, pp. 69-75.

[2] A. Jemal, F. Bray, M.M. Center, J. Ferlay, E. Ward, D. Forman, CA Cancer J. Clin., vol. 61, 2011, pp. 69-90.

[3] A. Urruticoechea, R. Alemany, J. Balart, A. Villanueva, F. Vinals, G. Capella, Curr. Pharm. Des., vol. 16, 2010, pp. 3-10.

[4] E.R. Jamieson, S.J. Lippard, Chem. Rev., vol. 99, American Chemical Society, 1999, pp. 2467-2498.

[5] R. Oun, Y.E. Moussa, N.J. Wheate, Dalton Transactions, vol. 47, The Royal Society of Chemistry, 2018, pp. 6645-6653.

[6] L. Zeng, P. Gupta, Y. Chen, E. Wang, L. Ji, H. Chao, Z.-S. Chen, Chem. Soc. Rev., vol. 46, 2017, pp. 5771-5804.

[7] A. Notaro, G. Gasser, Chem. Soc. Rev., vol. 46, 2017, pp. 7317-7337.

[8] F. Li, J.G. Collins, F.R. Keene, Chem. Soc. Rev., vol. 44, 2015, pp. 2529-2542.

[9] F.R. Keene, J.A. Smith, J.G. Collins, Coord. Chem. Rev., vol. 253, 2009, pp. 2021-2035.

[10] S. Monro, K.L. Colón, H. Yin, J. Roque III, P. Konda, S. Gujar, R.P. Thummel, L. Lilge,

C.G. Cameron, S.A. McFarland, Chem. Rev., vol. 119, 2019, pp. 797-828.

[11] C. Mari, V. Pierroz, S. Ferrari, G. Gasser, Chem. Sci., vol. 6, 2015, pp. 2660-2686.

[12] M. Jakubaszek, B. Goud, S. Ferrari, G. Gasser, Chem. Commun., vol. 54, 2018, pp. 1304013059.

[13] F. Heinemann, J. Karges, G. Gasser, Acc. Chem. Res., vol. 50, 2017, pp. 2727-2736.

[14] K. Qiu, Y. Chen, T.W. Rees, L. Ji, H. Chao, Coord. Chem. Rev., 2017.

[15] A. Yadav, T. Janaratne, A. Krishnan, S.S. Singhal, S. Yadav, A.S. Dayoub, D.L. Hawkins, S. Awasthi, F.M. MacDonnell, Mol. Cancer Ther., 2013.

[16] F.E. Poynton, S.A. Bright, S. Blasco, D.C. Williams, J.M. Kelly, T. Gunnlaugsson, Chem. Soc. Rev., vol. 46, The Royal Society of Chemistry, 2017, pp. 7706-7756.

[17] J. Shum, P.K.-K. Leung, K.K.-W. Lo, Inorg. Chem., vol. 58, American Chemical Society, 2019, pp. 2231-2247.

[18] A. Juris, V. Balzani, F. Barigelletti, S. Campagna, P.l. Belser, A. Von Zelewsky, Coord. Chem. Rev., vol. 84, 1988, pp. 85-277.

[19] K. Kalyanasundaram, Coord. Chem. Rev., vol. 46, 1982, pp. 159-244.

[20] S. Campagna, F. Puntoriero, F. Nastasi, G. Bergamini, V. Balzani, in: V. Balzani, S. Campagna (Eds.), Photochemistry and Photophysics of Coordination Compounds I, Springer Berlin Heidelberg, Berlin, Heidelberg, 2007, pp. 117-214.

[21] C. Mari, V. Pierroz, R. Rubbiani, M. Patra, J. Hess, B. Spingler, L. Oehninger, J. Schur, I. Ott, L. Salassa, Chem. Eur. J., vol. 20, 2014, pp. 14421-14436.

[22] Y. Ellahioui, M. Patra, C. Mari, R. Kaabi, J. Karges, G. Gasser, S. Gómez-Ruiz, Dalton Trans., 2019.

[23] H. Huang, B. Yu, P. Zhang, J. Huang, Y. Chen, G. Gasser, L. Ji, H. Chao, Angew. Chem. Int. Ed., vol. 54, 2015, pp. 14049-14052.

[24] C. Mari, V. Pierroz, S. Ferrari, G. Gasser, Chem. Sci., vol. 6, 2015, pp. 2660-2686.

[25] J.P. Sauvage, J.P. Collin, J.C. Chambron, S. Guillerez, C. Coudret, V. Balzani, F. Barigelletti, L. De Cola, L. Flamigni, Chem. Rev., vol. 94, 1994, pp. 993-1019.

[26] N. Grover, N. Gupta, P. Singh, H.H. Thorp, Inorg. Chem., vol. 31, 1992, pp. 2014-2020.

[27] B.T. Farrer, H.H. Thorp, Inorg. Chem., vol. 39, 2000, pp. 44-49.

[28] N. Grover, H.H. Thorp, J. Am. Chem. Soc., vol. 113, 1991, pp. 7030-7031.

[29] G.A. Neyhart, N. Grover, S.R. Smith, W.A. Kalsbeck, T.A. Fairley, M. Cory, H.H. Thorp, J. Am. Chem. Soc., vol. 115, 1993, pp. 4423-4428. 
[30] A. Jain, C. Slebodnick, B.S. Winkel, K.J. Brewer, J. Inorg. Biochem., vol. 102, 2008, pp. 1854-1861.

[31] K.K. Patel, E.A. Plummer, M. Darwish, A. Rodger, M.J. Hannon, J. Inorg. Biochem., vol. 91, 2002, pp. 220-229.

[32] C.-W. Jiang, H. Chao, H. Li, L.-N. Ji, J. Inorg. Biochem., vol. 93, 2003, pp. 247-255.

[33] Y. Liu, R. Hammitt, D.A. Lutterman, R.P. Thummel, C. Turro, Inorg. Chem., vol. 46, 2007, pp. 6011-6021.

[34] H.-Y. Ding, X.-S. Wang, L.-Q. Song, J.-R. Chen, J.-H. Yu, B.-W. Zhang, J. Photochem. Photobiol. A: Chem., vol. 177, 2006, pp. 286-294.

[35] A. Rilak, I. Bratsos, E. Zangrando, J. Kljun, I. Turel, Z.i.D. Bugarčić, E. Alessio, Inorg. Chem., vol. 53, 2014, pp. 6113-6126.

[36] B.P. Sullivan, J.M. Calvert, T.J. Meyer, Inorg. Chem., vol. 19, 1980, pp. 1404-1407.

[37] E.C. Constable, M.D. Ward, J. Chem. Soc., Dalton Trans., 1990, pp. 1405-1409.

[38] S. Katagiri, R. Sakamoto, H. Maeda, Y. Nishimori, T. Kurita, H. Nishihara, Chemistry-A European Journal, vol. 19, 2013, pp. 5088-5096.

[39] E.C. Constable, K. Harris, C.E. Housecroft, M. Neuburger, J.A. Zampese, CrystEngComm, vol. 12, 2010, pp. 2949-2961.

[40] M.W. Cooke, P. Tremblay, G.S. Hanan, Inorg. Chim. Acta, vol. 361, 2008, pp. 2259-2269.

[41] E. Constable, A.C. Thompson, D. Tocher, M. Daniels, New J. Chem., vol. 16, 1992, pp. 855-867.

[42] S. Mallakpour, M. Dinari, H. Hadadzadeh, M. Daryanavard, F. Roudi, Journal of fluorescence, vol. 24, 2014, pp. 1841-1848.

[43] E.C. Constable, P. Harverson, C.E. Housecroft, E. Nordlander, J. Olsson, Polyhedron, vol. 25, 2006, pp. 437-458.

[44] E.C. Constable, R.W. Handel, C.E. Housecroft, A. Farràn Morales, B. Ventura, L. Flamigni, F. Barigelletti, Chemistry-A European Journal, vol. 11, 2005, pp. 4024-4034.

[45] E.M. Hahn, N. Estrada-Ortiz, J. Han, V.F. Ferreira, T.G. Kapp, J.D. Correia, A. Casini, F.E. Kühn, Eur. J. Inorg. Chem., vol. 2017, 2017, pp. 1667-1672.

[46] Rigaku Oxford Diffraction, 2015.

[47] R. Clark, J. Reid, Acta Crystallogr. Sect. A: Found. Crystallogr., vol. 51, 1995, pp. 887897.

[48] CrysAlisPro (version 1.171.38.41), Rigaku Oxford Diffraction, 2016.

[49] O.V. Dolomanov, L.J. Bourhis, R.J. Gildea, J.A.K. Howard, H. Puschmann, J. Appl. Crystallogr., vol. 42, 2009, pp. 339-341.

[50] G.M. Sheldrick, Acta Crystallographica Section A: Foundations and Advances, vol. 71, 2015, pp. 3-8.

[51] G.M. Sheldrick, Acta Crystallographica Section C: Structural Chemistry, vol. 71, 2015, pp. 3-8.

[52] C.F. Macrae, P.R. Edgington, P. McCabe, E. Pidcock, G.P. Shields, R. Taylor, M. Towler, J.v.d. Streek, J. Appl. Crystallogr., vol. 39, 2006, pp. 453-457.

[53] K. Nakamaru, Bull. Chem. Soc. Jpn., vol. 55, 1982, pp. 1639-1640.

[54] S.J. Bruce, I. Tavazzi, V.r. Parisod, S. Rezzi, S. Kochhar, P.A. Guy, Anal. Chem., vol. 81, 2009, pp. 3285-3296.

[55] M. Kozlowska, P. Rodziewicz, D.M. Brus, J. Breczko, K. Brzezinski, Acta Crystallogr. Sect. Sect. E: Struct. Rep. Online, vol. 68, 2012, pp. m1414-m1415.

[56] D.C. Craig, M.L. Scudder, W.-A. McHale, H.A. Goodwin, Aust. J. Chem., vol. 51, 1998, pp. 1131-1140.

[57] M.L. Scudder, D.C. Craig, H.A. Goodwin, CrystEngComm, vol. 7, 2005, pp. 642-649.

[58] A.G. Walstrom, M. Pink, X. Yang, K.G. Caulton, Dalton Transactions, 2009, pp. 60016006. 
[59] S. Pyo, E. Pérez-Cordero, S.G. Bott, L. Echegoyen, Inorg. Chem., vol. 38, 1999, pp. 33373343.

[60] C.A. Tovee, C.A. Kilner, J.A. Thomas, M.A. Halcrow, CrystEngComm, vol. 11, 2009, pp. 2069-2077.

[61] C. Femoni, M.C. Iapalucci, G. Longoni, T. Lovato, S. Stagni, S. Zacchini, Inorg. Chem., vol. 49, 2010, pp. 5992-6004.

[62] K. Lashgari, M. Kritikos, R. Norrestam, T. Norrby, Acta Crystallographica Section C, vol. 55, 1999, pp. 64-67.

[63] C.-C. Lin, P. Wang, L. Jin, H.-H. Li, S.-K. Lin, Z.-R. Chen, J. Cluster Sci., vol. 26, 2015, pp. 1011-1022.

[64] C.R. Groom, I.J. Bruno, M.P. Lightfoot, S.C. Ward, Acta Crystallographica Section B: Structural Science, Crystal Engineering and Materials, vol. 72, 2016, pp. 171-179.

[65] M.L. Scudder, H.A. Goodwin, I.G. Dance, New J. Chem., vol. 23, 1999, pp. 695-705.

[66] M. Stone, G. Crosby, Chem. Phys. Lett., vol. 79, 1981, pp. 169-173.

[67] M. Beley, J.-P. Collin, J.-P. Sauvage, H. Sugihara, F. Heisel, A. Miehé, J. Chem. Soc., Dalton Trans., 1991, pp. 3157-3159.

[68] M. Maestri, N. Armaroli, V. Balzani, E.C. Constable, A.M.C. Thompson, Inorg. Chem., vol. 34, 1995, pp. 2759-2767.

[69] J.P. Collin, S. Guillerez, J.P. Sauvage, F. Barigelletti, L. De Cola, L. Flamigni, V. Balzani, Inorg. Chem., vol. 30, 1991, pp. 4230-4238.

[70] V. Pierroz, T. Joshi, A. Leonidova, C. Mari, J. Schur, I. Ott, L. Spiccia, S. Ferrari, G. Gasser, J. Am. Chem. Soc., vol. 134, 2012, pp. 20376-20387.

[71] J. Karges, P. Goldner, G. Gasser, Inorganics, vol. 7, 2019, pp. 4.

[72] R. Bonnett, G. Martınez, Tetrahedron, vol. 57, 2001, pp. 9513-9547.

[73] T.S. Mang, T.J. Dougherty, W.R. Potter, D.G. Boyle, S. Somer, J. Moan, Photochem. Photobiol., vol. 45, 1987, pp. 501-506.

[74] X. Zhang, M.A. Rodgers, The Journal of Physical Chemistry, vol. 99, 1995, pp. $12797-$ 12803.

[75] M. Ericson, S. Grapengiesser, F. Gudmundson, A. Wennberg, O. Larkö, J. Moan, A. Rosen, Lasers Med. Sci., vol. 18, 2003, pp. 56-62.

[76] P. Zhang, L. Pei, Y. Chen, W. Xu, Q. Lin, J. Wang, J. Wu, Y. Shen, L. Ji, H. Chao, Chemistry-A European Journal, vol. 19, 2013, pp. 15494-15503.

[77] J.-W. Liang, Y. Wang, K.-J. Du, G.-Y. Li, R.-L. Guan, L.-N. Ji, H. Chao, J. Inorg. Biochem., vol. 141, 2014, pp. 17-27. 